A list of Working Papers on the last pages

No. 199,1988

POTENTIALS AND PITFALLS OF PANEL

DATA - The Case of Job Mobility*

by

Anders Björklund**

Paper presented at the European Economic Association Meetings in Bologna, August 27-29, 1988. Forthcoming in the European Economic Review.

* I thank Dan Hamermesh, Yannis Ioannides and Anders Klevmarken for constructive comments.

** IUI and Institute for Social Research, University of Stockholm, S-116 91, Stockholm, Sweden

This is a preliminary paper. Comments are welcome.

Revised August 8, 1988

Nov., 1988 
The topic of this paper is the effect of job mobility - change of employer - on wages. The need for panel data is obvious in the sense that we are interested in studying an intertemporal relationship, namely the impact of an event at one time (job change) on a variable at another time (wages).

Panel data can also be used to control for omitted variables. In particular, techniques have been developed to exploit the information inherent in multiple waves of data on the dependent and independent variables of the basic model. The advantages obtained by using panel data to control for omitted variables are, however, not without theix costs. The purpose of this paper is to provide an illustration of the potentials and pitfalls of panel data used to estimate the effect of job mobility on wages.

A recently constructed Swedish data set - the Hus-data (see klevmarken 1984) - is used. The first collection of Hus-data was made in the spring of 1984. The respondents were interviewed about present wage rates, schooling, work experiences, etc. A second wave of interviews were made in the spring of 1986 with new questions about present wage rates and about labor force experiences during the twoyear period since the first interview. In particular detailed questions about job mobility were asked (see Björklund and Holmlund 11988 ) for further analysis of labor mobility based on the Husdatal. 
The point of departure is a typical wage equation of the Mincer type to which dummy variables for persons working nightshift and for persons who have changed employer are added:

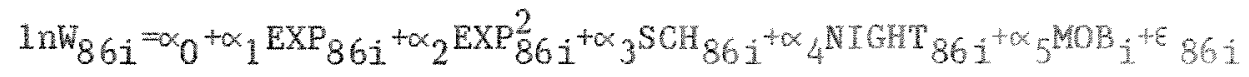

where $\ln _{86 i}$ is the natural logarithm of the worker's hourly wage rate in $1986, E_{8 X} i$ is years of work experience, $\mathrm{SCH}_{86 \mathrm{i}}$ is years of schooling, NIGHT $86 i$ is a dummy for persons working nightshift, $\mathrm{MOB}_{i}$ is a dummy for persons who have changed employer and $\varepsilon_{86} i$ is a stochastic error. Separate equations are estimated for men and women to allow for sex differences in human capital investments.

The usual way in labor economics for exploiting the additional information provided by panel data is to introduce individual permanent effects. The error term is decomposed into two parts, $\varepsilon_{86 i}=v_{i}+e_{86 i}$ " where $v_{i}$ is the individual permanent effect and $e_{86 i}$ is an i.i.d. disturbance. The permanent effect can represent ambition, intelligence and other unmeasured attributes which influence earnings. If these effects are correlated with the other independent variables, estimation of (1) on a crosssection from 1986 will produce biased results.

A corresponding equation can be specified for 1984 and the two waves of data can be used to estimate the difference between the two equations. In this way the individual effects have been netted out. The more general approach with more than two waves of data is to estimate the model on deviations of the variables from their means over time. This is known as the "within estimator" of the fixed-effects model. 
By netting out the individual permanent effects, two sources of bias can be avoided. Omitted-variable bias is avoided if the $v_{i}^{\prime} \mathrm{s}$ are predetermined variables which are correlated with the explanatory variables. In a more extended behavioral model of job mobility, the decision to change employer would be determined by the difference between the perceived gains and costs of moving. If the gains or costs are correlated with the $v_{i}$ 's but not with the transitory error, simultaneous-equation bias is avoided (see Heckman and Robb (1985) for an overview of estimators for such behavioral models).

If, however, the individual effects are not correlated with the explanatory variables, panel data can instead be used to improve efficiency over the pure cross-sectional specification. This is done by pooling the data from the two time periods. The individual effects will then give rise to heteroscedasticity which requires GLS estimation. Euller and Battese (1973) have shown that GLS estimates can easily be obtained by using oLs with transformed data:

$\mathrm{y}_{i}=y_{i t}-\lambda \bar{y}_{i}$ and $\mathrm{V}_{i}=x_{i t}-\lambda \bar{x}_{i} \quad$ where

$\lambda=1-\left(\frac{\sigma_{e}^{2}}{\sigma_{e}^{2}+T \sigma_{V}^{2}}\right)^{1 / 2}$

and $T$ is the number of waves of data. The variances can be obtained from estimates of the fixed-effects model, (formulated in deviations from means), which produces $\hat{\sigma}_{e}^{2}$, and from cross-sectional estimation of (1), which produces $\hat{\sigma}_{e}^{2}+\sigma_{\mathrm{V}}^{2}$.

This is known as the random-effects model, because the individual effects are treated as disturbances. Hence, only the mean and the variance need to be 
estimated, in contrast to the fixed-effects model in which each individual will have its own parameter $v_{i}$. As a consequence, the random-effects specification yields more efficient estimates of the regression coefficients, given that the assumption of independence between the individual effects and the explanatory variables is true. Hausman (1978) has developed a test of the independence assumption. In its general form the test is based on the difference between the random-effects and fixedeffects estimates. A convenient equivalent test in regression format, also proposed by Hausman, is to test $\beta=0$ from doing least squares on $\tilde{y}_{i}=\tilde{X}_{\alpha}+\tilde{x} \beta+u_{i}$, where $\tilde{x}$ is a vector of deviations from means.

Table 1 reports the results from estimating (2) on cross-section data from 1986 only, and from estimations of random-effects and fixed-effects specifications using panel data.

We first consider whether the Hausman test can reject the random-effects specification. 1 For men, the test of $\beta=0$ attains the E-value $F(4,537)=13.3$ and for women, $F(4,516)=1.3$. The hypothesis is strongly rejected for men but not for women. Consequently, the fixed-effects specification is preferred for men and the random-effects specification for women. To evaluate the merits of panel data, these estimates must be compared with those obtained from the cross-sectional specification. Is there a substantial difference? For men there is. The job mobility coefficient changes from an insignificant .023 to a significant .087 . The effect of work experience and schooling is also increased, even though the precision of the fixed-effects

1 Maddala (1987) suggests that this test is preceded by a test of $\sigma_{V}^{2}=0$ developed by Breusch and Pagan (1980). 
Table 1 Cross-section, random effects and fixedeffects estimates

standard errors in parentheses

\begin{tabular}{|c|c|c|c|c|c|c|}
\hline \multirow[b]{2}{*}{$\begin{array}{l}\text { Independent } \\
\text { variables }\end{array}$} & \multicolumn{3}{|c|}{ Men $(n=547)$} & \multicolumn{3}{|c|}{ Women $(n=522)$} \\
\hline & $\begin{array}{l}\text { Cross } \\
\text { section }\end{array}$ & $\begin{array}{l}\text { Random } \\
\text { effects }\end{array}$ & $\begin{array}{l}\text { Fixed } \\
\text { effects }\end{array}$ & $\begin{array}{l}\text { Cross } \\
\text { section }\end{array}$ & $\begin{array}{l}\text { Random } \\
\text { effects }\end{array}$ & $\begin{array}{l}\text { Fixed } \\
\text { effects }\end{array}$ \\
\hline $\begin{array}{l}\text { Years of work } \\
\text { experience }\end{array}$ & $\begin{array}{c}0.024 \\
(0.004)\end{array}$ & $\begin{array}{c}0.024 \\
(0.008)\end{array}$ & $\begin{array}{c}0.133 \\
(0.035)\end{array}$ & $\begin{array}{c}0.018 \\
(0.004)\end{array}$ & $\begin{array}{c}0.025 \\
(0.009)\end{array}$ & $\begin{array}{l}0.026 \\
(0.024)\end{array}$ \\
\hline $\begin{array}{l}\text { (Years of experi- } \\
\text { ence squared } / 1000 \text { ) }\end{array}$ & $\begin{array}{l}-0.296 \\
(0.080)\end{array}$ & $\begin{array}{l}-0.299 \\
(0.134)\end{array}$ & $\begin{array}{l}-0.271 \\
(0.137)\end{array}$ & $\begin{array}{c}-0.307 \\
(0.087)\end{array}$ & $\begin{array}{l}-0.429 \\
(0.171)\end{array}$ & $\begin{array}{l}-0.334 \\
(0.214)\end{array}$ \\
\hline Years of schooling & $\begin{array}{c}0.046 \\
(0.003)\end{array}$ & $\begin{array}{l}0.045 \\
0.005\end{array}$ & $\begin{array}{r}0.166 \\
0.052\end{array}$ & $\begin{array}{c}0.037 \\
(0.003)\end{array}$ & $\begin{array}{l}0.033 \\
(0.007)\end{array}$ & $\begin{array}{l}-0.062 \\
(0.058)\end{array}$ \\
\hline Nightshift & $\begin{array}{l}0.039 \\
(0.098)\end{array}$ & $\begin{array}{l}0.076 \\
(0.059)\end{array}$ & $\begin{array}{c}0.072 \\
(0.052)\end{array}$ & $\begin{array}{l}0.111 \\
(0.046)\end{array}$ & $\begin{array}{l}0.083 \\
(0.047)\end{array}$ & $\begin{array}{c}0.094 \\
(0.048)\end{array}$ \\
\hline Job mobility & $\begin{array}{c}0.023 \\
(0.036)\end{array}$ & $\begin{array}{c}0.051 \\
(0.023)\end{array}$ & $\begin{array}{c}0.087 \\
(0.022)\end{array}$ & $\begin{array}{l}-0.024 \\
(0.042)\end{array}$ & $\begin{array}{c}0.041 \\
(0.032)\end{array}$ & $\begin{array}{c}0.081 \\
(0.035)\end{array}$ \\
\hline$\overline{\mathrm{R}}^{2}$ & 0.303 & 0.117 & 0.051 & 0.191 & 0.047 & 0.019 \\
\hline
\end{tabular}

Note: The $\bar{R}^{2}$ 's are not comparable because the dependent variables are not the sarae. 
estimates is lower than the cross-section estimates. Other results, not presented here, show that the effects of work experience remain when age is added to the explanatory variables. Hence, there is an effect of work experience per se.

The value of panel data for women is not obvious. The random-effects estimates are very similar to those obtained from the cross section. The job mobility coefficient is raised from -.024 to .041 but as the standard errors are large this is not overly revealing.

\section{Measurement errors}

The advantage of panel data to control for individual fixed-effects is, however, obtained at some cost. A common experience in labor economics applications of fixed-effects models is that one has imprecise estimates of the coefficients of interest and very low explanatory power; $\mathrm{R}^{2}$ 's less than .02 are frequent. Those experiences have led Hamermesh (1987) to ask: Why do fixed-effects models perform so poorly?

This is a natural question to ask after having seen the results above, too, in particular the results for women. The $\overline{\mathrm{R}}^{2} \mathrm{~s}$ were low and some standard errors were large. The standard errors of the schooling coefficients were .052 (men) and .058 (women) compared to .003 in the cross-section model.

A possible explanation for these results is measurement errors, which might have more severe consequences in fixed-effects models than in crosssectional applications. Errors in the independent 
variables are most serious because the parameters will be biased downward (towards zero). If the true independent variable is measured by $x_{i t}$ with an error $\xi_{i t}$, which is serially uncorrelated, the plim of the difference estimator will be

$$
\operatorname{plim} b_{d}=\rho\left(1-\frac{2 \sigma^{2} \xi}{\operatorname{var}(d x)}\right)
$$

where $\beta$ is the true parameter.

In particular when the variance of the true changes is small relative to the measurement errors the downward bias might be strong. 1 Hence, 10 w and insignificant coefficients might be expected in fixed-effects models.

We do not believe that the problem created by measurement errors in the independent variables outweighs the advantage of controling for fixed effects in this application for two reasons. First, the crucial parameter - the coefficient for job mobility - is estimated higher by the fixed-effects specification than by the cross-section model. The same holds true for the effect of working nightshift on men. Second, the changes in the basic independent variables experience and schooling are measured directly in the Hus-data, not by differencing two levels measured at two points of time. In the 1986 interviews the respondents were asked about their activities during the two-year period from 1984. Therefore the variances of two measurement errors are not added to each other.

I Note though that positively serie-correlated measurement errors reduce the problem and might make first difference models superior to crosssection models. Fixed measurement errors are of course "differenced away" in fixed-effects model. 
Measurement errors in the dependent variable can, however, be the major reason for the low precision of the estimates and the low $\overline{\mathrm{R}}^{2}$ in the fixed-effects specification. 1 It is very tricky to measure hourly wage rates. Only some few workers report their wage rate directly; probably many workers do not know their wage rate. Instead questions are asked about wage earnings for a week, month or year and the number of working hours. An error in any of these variables will create an error in the hourly wage rate. Because most men work close to the standard work week of 40 hours, whereas many women do not, it is Iikely that the scope for measurement errors is higher for women. This might explain the poor performance of the fixed-effects model for women.

\section{Sample attrition}

The panel data techniques require information from at least two time periods for each individual. Another problem which arises is that some of the respondents from 1984 cannot be reinterviewed and the analysis has to be made on a sample which might be non-random.

One way to shed light on this problem is to compare the wage determinants in 1984 between those who disappear and those who are reinterviewed 1986. If the differences are small, the sample attrition is less likely to create bias although efficiency losses are made.

1 Hamermesh (1987) shows that greater measurement errors in the dependent variable reduce the $\mathrm{R}^{2}$ in the fixed-effects model compared to the crosssection specification if the autocorrelation in the dependent variable exceeds the autocorrelation in the measurement error. 
Table 2 reports the estimates of equations for the total sample with positive wages in 1984 (columns A), for the subsample with positive wages both 1984 and 1986 (columns B) and for the attrited sample (columns $C$ ). It appears that sample attrition is rather high; about one third of those with positive wages in 1984 either do not respond at all in the 1986 survey or have left the labor force. 1 Therefore the potential bias created by making the analysis on only two thirds of the original sample might be strong.

The estimates do not, however, support the view that sample attrition is a severe problem, at least not for men. The hypothesis that the wage determinants in 1984 are the same for those who remain in the sample and those who leave it cannot be rejected at the ten percent level. Even more important, the estimated coefficients in columns $A$ and $B$ for men are very close and the differences can be neglected from an economic point of view. For example, the differences in the experience coefficients imply that wages peak after 39 years for the total sample and after 44 years for the subsample with positive wages in both 1984 and 1986 .

The situation is more problematic for women. The differences in the coefficients between the two subsamples are larger and the hypothesis that they are equal can be strongly rejected. Consequently the sample attrition cannot be regarded as random. What matters from the viewpoint of an applied economist is, however, whether the absolute differences between columns $A$ and $B$ are economically

1 It is a matter of judgement whether those who leave the labor force are non-respondents or not. By treating them as such we define attrition in a broad way. 
Table 2 Estimated wage equations for the total sample (A), the subsample with positive wages both 1984 and 1986 (B) and the subsample with positive wages 1984 but not 1986 (c).

Dependent variable: In wage 1984. Standard errors in parentheses.

\begin{tabular}{|c|c|c|c|c|c|c|}
\hline \multirow{2}{*}{$\begin{array}{l}\text { Independent } \\
\text { variables }\end{array}$} & \multicolumn{3}{|l|}{ Men } & \multicolumn{3}{|l|}{ Women } \\
\hline & A & $B$ & $\mathrm{c}$ & A & B & $\mathrm{C}$ \\
\hline Constant & $\begin{array}{c}2.920 \\
(0.049)\end{array}$ & $\begin{array}{c}2.989 \\
(0.056)\end{array}$ & $\begin{array}{c}2.849 \\
(0.092)\end{array}$ & $\begin{array}{c}3.086 \\
(0.043)\end{array}$ & $\begin{array}{l}3.062 \\
(0.056)\end{array}$ & $\begin{array}{l}3.132 \\
(0.066)\end{array}$ \\
\hline $\begin{array}{l}\text { Years of work } \\
\text { experience }\end{array}$ & $\begin{array}{c}0.030 \\
(0.003)\end{array}$ & $\begin{array}{c}0.025 \\
(0.004)\end{array}$ & $\begin{array}{l}0.035 \\
(0.005)\end{array}$ & $\begin{array}{c}0.019 \\
(0.003)\end{array}$ & $\begin{array}{c}0.017 \\
(0.004)\end{array}$ & $\begin{array}{c}0.021 \\
(0.005)\end{array}$ \\
\hline $\begin{array}{l}\text { (Years of work expe- } \\
\text { rience squared)/1000 }\end{array}$ & $\begin{array}{l}-0.386 \\
(0.057)\end{array}$ & $\begin{array}{l}-0.282 \\
(0.077)\end{array}$ & $\begin{array}{l}-0.453 \\
(0.098)\end{array}$ & $\begin{array}{l}-0.282 \\
(0.066)\end{array}$ & $\begin{array}{l}-0.268 \\
(0.086)\end{array}$ & $\begin{array}{l}-0.292 \\
(0.102)\end{array}$ \\
\hline Years of schooling & $\begin{array}{c}0.047 \\
(0.003)\end{array}$ & $\begin{array}{c}0.047 \\
(0.003)\end{array}$ & $\begin{array}{c}0.046 \\
(0.006)\end{array}$ & $\begin{array}{c}0.034 \\
(0.003)\end{array}$ & $\begin{array}{c}0.039 \\
(0.003)\end{array}$ & $\begin{array}{c}0.027 \\
(0.004)\end{array}$ \\
\hline Nightshift & $\begin{array}{l}-0.056 \\
(0.098)\end{array}$ & $\begin{array}{l}-0.071 \\
(0.113)\end{array}$ & $\begin{array}{c}-0.027 \\
(0.181)\end{array}$ & $\begin{array}{c}0.111 \\
(0.037)\end{array}$ & $\begin{array}{c}0.181 \\
(0.046)\end{array}$ & $\begin{array}{c}0.006 \\
(0.059)\end{array}$ \\
\hline n & 814 & 547 & 267 & 809 & 522 & 287 \\
\hline$\overline{\mathrm{R}}^{2}$ & 0.334 & 0.352 & 0.307 & 0.203 & 0.222 & 0.197 \\
\hline $\begin{array}{l}\text { F-statistic } \\
\text { for chow-test }\end{array}$ & & 1.43 & & & 3.28 & \\
\hline
\end{tabular}

a Critical values: $3.02(1 \%), 2.21(5 \%)$ and $1.85(10 \%)$. 
important. It appears that the experience profiles are very similar - peaks after 34 and 32 years respectively - and the returns to schooling are 3.4 and 3.9 percent respectively. The most problematic variable is nightshift which is associated with a wage premium of 11.1 percent in the total sample and 18.1 percent in the subsample on which the panel data techniques can be applied.

\section{5}

The dynamic specification

The usefulness of a panel data set with only two waves, like the Hus-data in its present state, depends on the dynamic structure of earnings. Two dynamic mechanisms have been considered in the literature. In the state dependence model past values of wages have a causal effect on present wages. In autoregressive models the error term is serially correlated.

If the true model contains both fixed effects and any of these dynamic mechanisms, additional waves of data are needed to estimate the full model. Even worse, the fixed-effects model estimated on two waves as above will be biased (Nickell (1981)). The size of this bias in practical applications is hard to ascertain. Edin (1988) reports the results from an application where the average change in the parameters is 1.24 standard errors when serial correlation is taken into account in a fixed-effects model. His dependent variable is not hourly wage rates but weekly wage earnings, which capture the effect of working hours per week. In addition, the time interval between the waves was only one year. Therefore his results do not necessarily apply to this study. 
With only two waves of data, the best one can do is to estimate different models and see whether the coefficients of interest are sensitive to the model specification. A state dependence model is obtained if lagged wages are added to equation (1). I If the error term in (1) follows a first order serial correlation and is substituted into the equation, the following equation is obtained:

$$
\begin{aligned}
& \operatorname{InW}_{86 i}=\alpha_{0}(1-\delta)+\alpha_{1} \operatorname{EXP}_{86 i^{-\alpha_{1}}} \operatorname{EXX}_{84 i}+\alpha_{2} \operatorname{EXP}_{86 i^{-}}^{2} \alpha_{2} \delta \operatorname{EXP}_{84 i}^{2}+
\end{aligned}
$$

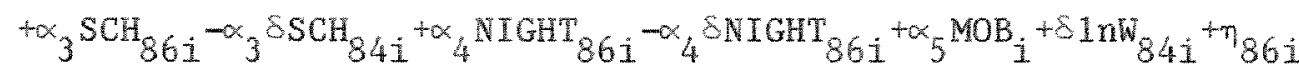

where $\delta$ is the serial correlation coefficient and $\eta 86 i$ is the i.i.d. disturbance.

The restrictions in (4) imply that the empirical implications of the autocorrelation model can be tested. 2 .

Table 3 reports the estimates of the state dependence and the autoregressive models. Fortunately the estimated job mobility coefficient is not very sensitive to choice of dynamic specification and quite close to the results obtained in the models with individual effects too. This result does not rule out the possibility that models which are

1 Heckman, Hotz and Dabos (1987) use lagged earnings as a "control function" to purge the equation of dependence between mobility and the error term. This is another rationale for this specification.

2 The restrictions are non-linear. Amemiya (1985) suggests the following test:

$\left(\mathrm{n}\left[\mathrm{SSR} \mathrm{ur}_{\mathrm{r}}-\mathrm{SSR}_{\mathrm{r}}\right]\right) / \mathrm{SSR}_{\mathrm{r}}$

where SSR denotes the sum of squared residuals and the subscripts $r$ and ur denote the restricted and unrestricted model. The statistic is chi-square distributed with degrees of freedom equal to the number of restrictions. 
Table 3 Estimates of dynamic models

standard errors in parentheses

\begin{tabular}{|c|c|c|c|c|}
\hline & Men & & Women & \\
\hline $\begin{array}{l}\text { Independent } \\
\text { variables }\end{array}$ & $\begin{array}{l}\text { State } \\
\text { dependent } \\
\text { mode1 }\end{array}$ & $\begin{array}{l}\text { Auto- } \\
\text { regressive } \\
\text { model }\end{array}$ & $\begin{array}{l}\text { State } \\
\text { dependent } \\
\text { model }\end{array}$ & $\begin{array}{l}\text { Auto- } \\
\text { regressive } \\
\text { model }\end{array}$ \\
\hline Constant & $\begin{array}{c}0.669 \\
(0.089)\end{array}$ & $\begin{array}{c}0.630 \\
(0.102)\end{array}$ & $\begin{array}{l}1.193 \\
(0.016)\end{array}$ & $\begin{array}{l}1.149 \\
(0.123)\end{array}$ \\
\hline $\begin{array}{l}\text { Years of work } \\
\text { exp. } 1986\end{array}$ & $\begin{array}{c}0.003 \\
(0.003)\end{array}$ & $\begin{array}{c}0.022 \\
(0.018)\end{array}$ & $\begin{array}{c}0.007 \\
(0.003)\end{array}$ & $\begin{array}{c}0.026 \\
(0.011)\end{array}$ \\
\hline $\begin{array}{l}\text { Years of work } \\
\text { experience } \\
\text { squared/1000 } 1986\end{array}$ & $\begin{array}{l}-0.061 \\
(0.049)\end{array}$ & $\begin{array}{l}-0.275 \\
(0.245)\end{array}$ & $\begin{array}{l}-0.148 \\
(-2.21)\end{array}$ & $\begin{array}{r}-0.450 \\
(0.188)\end{array}$ \\
\hline $\begin{array}{l}\text { Years of } \\
\text { schooling } 1986\end{array}$ & $\begin{array}{c}0.007 \\
(0.002)\end{array}$ & $\begin{array}{c}0.043 \\
(0.012)\end{array}$ & $\begin{array}{c}0.011 \\
(0.003)\end{array}$ & $\begin{array}{c}0.032 \\
(0.008)\end{array}$ \\
\hline $\begin{array}{l}\text { Nightshift } \\
1986\end{array}$ & $\begin{array}{c}0.047 \\
(0.058)\end{array}$ & $\begin{array}{c}0.073 \\
(0.053)\end{array}$ & $\begin{array}{c}0.012 \\
(0.036)\end{array}$ & $\begin{array}{c}0.084 \\
(0.047)\end{array}$ \\
\hline $\begin{array}{l}\text { Log wage } \\
1984\end{array}$ & $\begin{array}{c}0.843 \\
(0.027)\end{array}$ & $\begin{array}{c}0.843 \\
(0.027)\end{array}$ & $\begin{array}{c}0.671 \\
(0.034)\end{array}$ & $\begin{array}{c}0.675 \\
(0.034)\end{array}$ \\
\hline Job mobility & $\begin{array}{c}0.056 \\
(0.021)\end{array}$ & $\begin{array}{c}0.061 \\
(0.022)\end{array}$ & $\begin{array}{c}0.043 \\
(0.032)\end{array}$ & $\begin{array}{c}0.045 \\
(0.032)\end{array}$ \\
\hline$n$ & 547 & 547 & 522 & 522 \\
\hline $\begin{array}{l}\text { Sum of squared } \\
\text { residuals }\end{array}$ & 10.79 & 10.77 & 16.79 & 16.73 \\
\hline$\overline{\mathbb{R}}^{2}$ & 0.752 & - & 0.535 & - \\
\hline
\end{tabular}


more general can produce different estimates of the returns to job mobility. 1

The non-linear restrictions in (4) could be rejected for men but not for women. For men we can consequently rule out the autocorrelation model.

\section{6}

Conclusions

The main advantage of panel data, to control for individual fixed effects, turned out to be very important in this application. The job mobility coefficient for men was close to zero and insignificant in the cross-sectional specification but markedly higher and significant when fixed effects were controlled for. A Hausman test rejected the null hypothesis of independence between the individual effects and the explanatory variables.

However, this advantage of panel data is obtained at some cost. The $\bar{R}^{2}$ and the precision of especially the schooling coefficient were low in the fixed-effects model. This result, although common, is not necessarily a consequence of the model per se, but probably caused by high measurement errors in wage data constructed from survey questions about wage earnings and working hours. In a study based on pure administrative data without any measurement errors, Hamermesh (1987) reported much higher explanatory power. Future surveys should pay more attention to the questions used to construct hourly wage rates. Administrative data records should also be considered.

1 The American studies of the effect of training programs are very sensitive to the dynamic specification. Heckman, Hotz and Dabos (1987) is a recent attempt to discriminate between different models. 
Due to sample attrition, we could apply the panel data techniques to only two thirds of the original sample. Fortunately it turned out, though, that the 1984 wage equation in the remaining sample was very similar to the equation for the total sample, at least for men.

The proper dynamic specification of wages is an unresolved issue. General models which incorporate both fixed effects and dynamic mechanisms require more than two waves of data to be estimated. In addition, fixed-effects models estimated from two waves as in this paper will be biased if such dynamic mechanisms are present. Additional waves of data are therefore needed. Beside checking the results obtained in this study, such data will be of value in themselves since they will describe wage differentials in a long-term perspective. Furthermore, Griliches and Hausman (1986) have developed techniques to handle exrors in the independent variables which require additional waves of data. unfortunately, though, the sample attrition problem might become even greater if additional waves are required.

\section{REFERENCES}

Amemiya, T., 1985, Advanced econometrics, Basil Blackwell, oxford.

Björklund, A., B. Holmlund, 1988, "Job mobility and subsequent wages in Sweden", in J. V. Dijk et al. (editors) Migration and Labor Market Adjustment, Kluwer, Dortrecht.

Breusch, T., A. Dagan, 1980, "The Lagrange multiplier test and its applications to model specification in Econometrics", Review of Economic studies $47,239-253$. 
Edin, P.-A., 1988, Individual consequences of plant closures, uppsala University, Department of Economics.

Fuller, W., G. Battese, 1973, "Transformations for estimation of linear models with nested error structure" Journal of the American Statistical Association 68, 626-632.

Griliches, Z. J. Hausman, 1986, "Errors in variables in panel data", Joumal of Econometrics 31. $93-118$.

Hamermesh, D., 1987, Why do fixed-effects model perform so poorly? The case of academic salaries. Working Paper No. 2135, National Bureau of Economic Research

Hausman, J., 1978, "Specification tests in econometrics", Econometrica 46, 1251-1271.

Heckman, J., R. Robb JI., 1985, "Alternative Methods for Evaluating the Impact of Interventions - an Overview", Journal of Econometrics 30 , $239-267$.

Heckman, J., V. Hotz and M. Dabos, 1987, "Do we need experimental data to evaluate the impact of manpower traning on earnings?" Evaluation Review Vol. 11, No. 4, 395-427.

Klevmarken, A., 1984, "Household market and nonmarket activites. The first year of a swedish panel study". The 1984 Business and Economic Statistics Section Proceedings of the American Statistical Association and Vierteljahrshefte zur Wirtschaftsforschung, Heft 4 1984, Deutsches Institut fur Wirtschaftsforschung.

Maddala, G., 1987, "Limited dependent variable models using panel data" Journal of Human Resources XXI.3, 308-338.

Nickel1, S., 1981, "Biases in dynamic models with fixed effects". Econometrica 49, 1417-1426. 